\title{
Does Social Media Marketing Work in Chinese Luxury Market?
}

\author{
Wan Yuan \\ ICN Business School
}

Maxime Koromyslov

ICN Business School

\author{
Chang Jian Cong \\ Shanghai Jian Qiao University \\ Xin Qing \\ Shanghai Jian Qiao University \\ Lu Huiwen \\ Shanghai Jian Qiao University
}

This paper is mainly aimed to explore how social marketing makes contribution on luxury market. The authors analyse WeChat, this prevailing social media application with both instantons messaging and Customer engagements in China, to examine how social marketing influences the Chinese luxury purchaser. 363 questionnaires have been collected and validated. Confirmatory factor analysis, exploratory factor analysis, cluster analysis and path analysis have been used in this research to verify whether social media marketing is effective and efficient for luxury marketing in China. This paper unveils whether traditional social marketing is effectively in luxury industry. It has approved that only customer engagement has positive effective in luxury marketing in China. The Chinese young consumers tend to seek advices by blogger, instead of luxury company marketing campaign.

Keywords: WeChat, luxury, social marketing, customer engagement, para social interaction, key opinion leader

\section{INTRODUCTION}

The world is rapidly going social and online. In December 2016, the world internet usage population has increased by $923.9 \%$ comparing with the same figure in the end of 2000 (Internet World States, 2017). Technology, especially the internet technology, has led to the marketing environment to change dramatically and customers have gained significant market power. Nowadays, marketing becomes more complex and data-driven, and achieves more customers than it did several years ago (O'Connor, 2015). Along with the rapid prevalence of social media and networking application (such as Facebook, twitter, 
WeChat), social marketing is integrating in consumers' lives in all over the world, influencing their consumers behavior and purchase decisions. Social media platforms have become nearly ubiquitous among adolescent users in all over the world (Bond, 2016). Social media have all the features of internetbased platforms (Yi et al, 2016). Social marketing requires people with social enthusiasm and a widelyused instant messaging application. China is a socially connected society and more than $60 \%$ of Chinese adults use online social networking sites (PEW Research Center, 2016). However, comparing with its neighboring countries, it has still growth potential. The internet penetration rate (internet users per population) in China has reached at $52.7 \%$, lower than in Japan $(91.3 \%)$ and South Korea $(89.4 \%)$ (Internet World Stats, 2017). In China, WeChat is the most popular instant message application. WeChat (WeiXin in Chinese, literally means micro talking) is a mobile instant, text, voice, picture, video messaging communication service application developed by Tencent Holing Ltd. In China on January 21, 2011 (Tencent, 2017). It is claimed that more than 800 million people using WeChat to send voice message, video, picture, word and group-chatting (Tencent, 2017). Different from the similar instant message application, such as WhatsApp and line, WeChat has developed the functions of blogging (known as WeChat Publication, or GongZhongHao in Chinese), online payment tool (WeChat Wallet), social network service (WeChat Moment), city service and mini program. Not only the people spend lots of time to maintain and extend their relationships (Lin \& Lu, 2011a; Ellison et al., 2007; Boyd \& Ellison, 2007; Powell, 2009) by refreshing their online statue, sending mails, sharing videos, broadcasting their knowledge, but also the E-Commerce merchandisers are advertising their goods and services by WeChat Publication and Moments platforms.

However, WeChat faces few competitors in China. Due to the national security concern, Chinese government has blocked Facebook, Instagram, Twitter and YouTube (except Hong Kong, Macau and Taiwan). The user of above mentioned should only use VPN to $\log$ in their account, but the VPN providers are facing tenser and tenser regulation (Techradar, 2018). The block of above websites or application provides WeChat a very good opportunity to expand its instantons message and social media market. Table 1 shows the main function of WeChat tool.

TABLE 1

MAIN FUNCTION OF THE TOOLS OF WECHAT

\begin{tabular}{|l|l|l|l|}
\hline & & \multicolumn{1}{|c|}{$\begin{array}{c}\text { Reference } \\
\text { Example }\end{array}$} & \multicolumn{1}{c|}{ Description } \\
\hline 1 & $\begin{array}{l}\text { WeChat } \\
\text { Moment }\end{array}$ & $\begin{array}{l}\text { Instagram or } \\
\text { Facebook }\end{array}$ & $\begin{array}{l}\text { People could post their photo and experience and his/her } \\
\text { friends could express a "like" and comment it. }\end{array}$ \\
\hline 2 & WeChat Group & $\begin{array}{l}\text { Like WhatsApp } \\
\text { group }\end{array}$ & $\begin{array}{l}\text { Several people could have conversation in a specific chat } \\
\text { room, allowing them to transmit photo, voice, location and } \\
\text { etc. }\end{array}$ \\
\hline 3 & $\begin{array}{l}\text { WeChat Public } \\
\text { Account }\end{array}$ & Like LinkedIn & $\begin{array}{l}\text { The company could create WeChat Public Account to } \\
\text { publish the news }\end{array}$ \\
\hline 4 & Money & Like Apply Pay & $\begin{array}{l}\text { The users could combine their bankcard and generator QR } \\
\text { code. Via QR code, the shoppers could use scanner to finish } \\
\text { the payment process. }\end{array}$ \\
\hline 5 & WeChat Game & $\begin{array}{l}\text { Steam in mobile } \\
\text { platform }\end{array}$ & $\begin{array}{l}\text { WeChat plays a role in introducing the users to its mobile } \\
\text { game platform. }\end{array}$ \\
\hline
\end{tabular}




\section{FIGURE 1 \\ (FROM LEFT TO RIGHT) WECHAT MOMENT, WECHAT GROUP, WECHAT PUBIC ACCOUNT AND WECHAT MONEY}

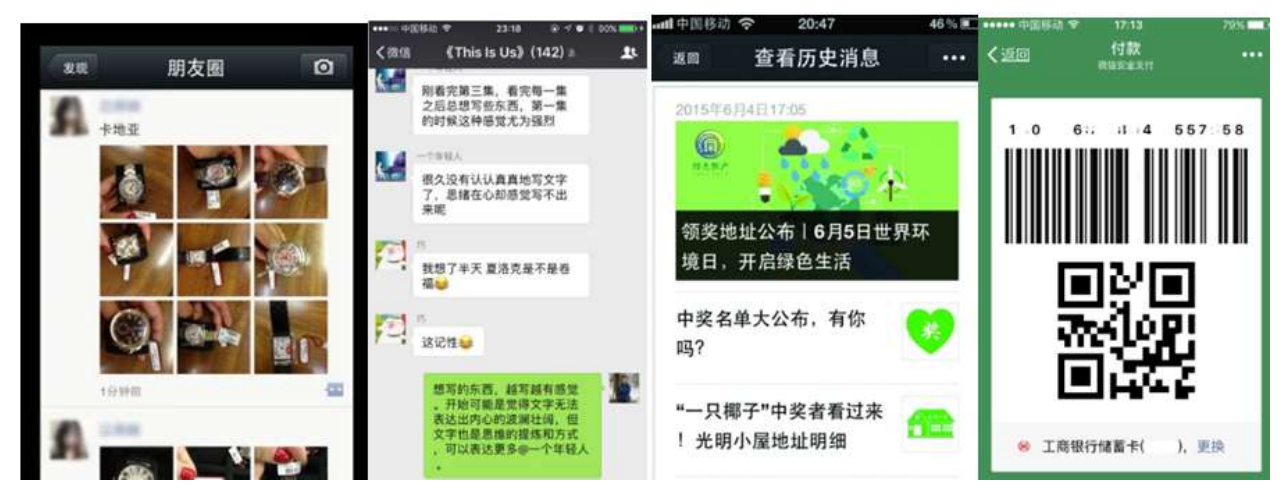

Every industry should not ignore the huge opportunity derived from social media marketing. Under this background, luxury goes social and omnichannel (Boston Consulting Group, 2017) and tries to embrace the social media marketing. The luxury brands, such as Channel, Dior, Burberry and Prada have already applied the social media strategies to be familiar with their customers (Dhaoui, 2014; Mike, 2014; Park, Song,\&Ko, 2011). Burberry is the among the first luxury companies to start its digital marketing in 2006 (Burberry, 2006; DIGIDAY, 2015). In 2009, online luxury sales only accounted for only $2 \%$ of overall luxury sales in the world. From 2009 to 2014, the online luxury sales have grown at a much faster rate $(27 \%$ per year) than offline luxury sales $(7 \%)$ (McKinsey, 2014). The share of online sales has reached $11 \%$ in 2019 . It is widely acknowledged that digital tools will play an increasing important role in fashion and luxury marketing. In fashion industry, social marketing has been applied extensively. Chiara Ferragni is one of the most successful fashion influencer in the world. She started her blog in 2009 when she was a student of Bocconi University in Milan, one of the top business schools in the world. She has 10.2 million followers in her Instagram until October 2017.

Some luxury companies feel reluctant to embrace the social media marketing due to the reason that digital tools may have negative fact on consumers' sensory experience of luxury goods, however, social media marketing has provided novel opportunity to be familiar with the customers (Baker Retailing Center, 2015). Since 21st century, the consumption for luxury brands was growing in the emerging economies of China, India, Asia, the Middle East and Latin America (Verdict, 2007; Chadha and Husband, 2006; Boston Consulting Group, 2017). However, in recent year, as the one of the largest luxury consumption countries, the percentage of Chinese consumers' contribution to global luxury contributions declined from 31\% in 2015 to 30\% in 2016 (Bain, 2016), which signals that Chinese luxury market growth rate decelerated. However, the long-term outlook on Chinese luxury consumption is still positive, as Chinese middle-income class is still expanding and there is no sign that Chinese economy will stagnate in near future. It is estimated that in 2020 Chinese luxury market share will reach at $44 \%$ of global market (Branigan, 2011). 


\section{FIGURE 2 \\ WECHAT PUBLICATION ACCOUNT OF LOUIS VUITTON AND CHANNEL}

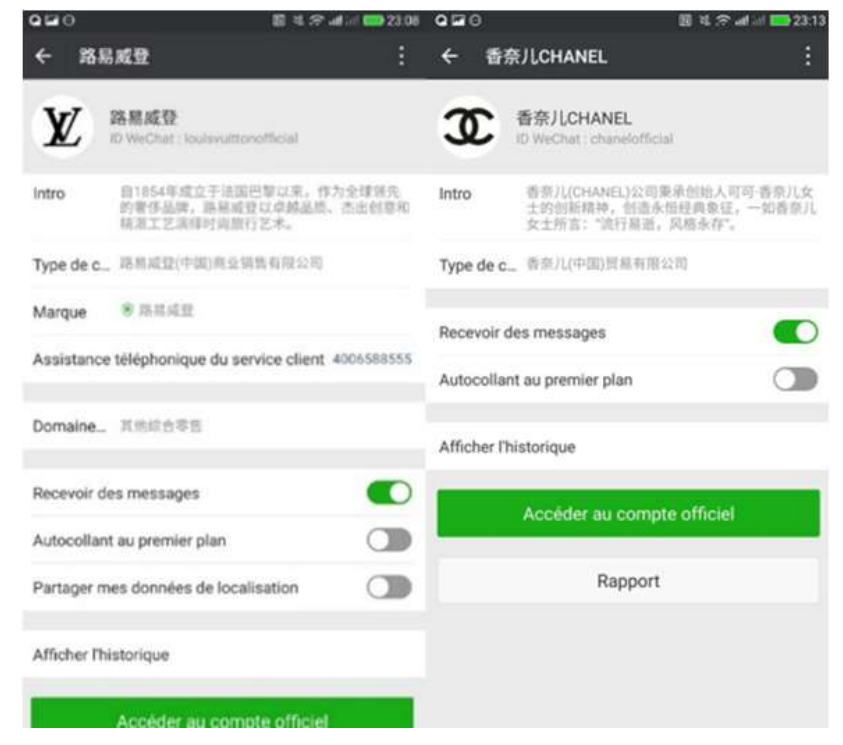

Several scholars addressed that promotional activities could be conducted in the social media platforms (i.e. Chang et al., 2015; De Vries et al., 2012; Hill and Moran, 2011). However, promotion and discount may jeopardize the luxury brand image (Kapferer, 2012), especially in social media platform. Both academism and practitioner need to examine how social media promotes the luxury goods to their customers, while retaining the sensory and general image of luxury goods.

The value of this paper is dedicated in finding how social media promotes the sales of luxury goods in China. The paper is structured into four parts: the first part is to state the literature review; the second part is to structure the hypothesis model and the third part is methodology and data analysis; the fourth part is to conclude an advice.

\section{LITERATURE REVIEWS AND HYPOTHESIS DEVELOPMENT}

\section{Luxury and Its Customers}

The booming prospect of luxury market has attracted the interest from researchers (Ko, E.,2017). The definition of what 'luxury' can vary according to a person or country or any other situation, making it difficult to provide a universal definition recognized by academic world. In Xinhua dictionary (like Oxford dictionary for English), luxury means unnecessary high-class lavish goods (Xinhua Dictionary, 2017). It is interesting to be noted that although China and Japan have culture similarity in occidental country's view. However, their attitude towards luxury are different (Kapfere, 2013). Japanese people speak of 'lugujuri' (phonetic adaptation of luxury). They refer not to the concept but to what they experience in the stores of prestige brands (especially global known brand) anywhere in the world. In occidental world, Luxury is based on the notions of scarcity, social recognition, and superior quality, and it is consumed in the pursuit of unique, sensory-rich, and psychologically gratifying experiences that define the individual (Frank 1999, Veblen 1899). "Veblen effect" demonstrates that the motive to buy luxurious products to show their wealth and higher social class. Leibenstein (1950) supplement "Veblen effect" with snob effect and bandwagon effect. Snob effect refers to the effect that the demand for some specific good falls while the number of the buyers increases. Meanwhile, as the household income increases, the customers tend to imitate the "high-class" consumer behavior. The bandwagon effect refers to the situation that the demand of luxury goods increases as the number of high-class consumers increase. Vigneron and Johnson $(1999,2004)$ were among the pioneers to explore the "brand luxury 
index" and proposing five dimensions in its framework, which has been summarized as the charts bellows:

E.Ko (2017) defines the measurement of luxury brands as Quality, Authenticity, prestigious image, commands premium price and resonance.

TABLE 2

THE MEASUREMENT OF LUXURY BRANDS DEFINED BY E.KO (2017)

\begin{tabular}{|c|c|l|}
\hline & Criteria & \multicolumn{1}{c|}{ Items } \\
\hline 1 & Quality & $\begin{array}{l}\text { 1) This brand is of a high quality 2) This is a superior brand 3) This brand } \\
\text { is highly sophisticated }\end{array}$ \\
\hline 2 & Authenticity & $\begin{array}{l}\text { 1) The brand remains true to its espoused values 2) The brand reflects a } \\
\text { timeless design. 3) Quality is central to the brand. }\end{array}$ \\
\hline 3 & Prestigious image & $\begin{array}{l}\text { 1) This brand is a symbol of prestige 2) This is a premium brand 3) This is } \\
\text { a high-end brand }\end{array}$ \\
\hline 4 & $\begin{array}{l}\text { Commands premium } \\
\text { price }\end{array}$ & $\begin{array}{l}\text { 1) Even if the other brands are priced lower, I will still buy brand X } \\
\text { pay more } \\
\text { 3) I am willing to pay a higher price for brand X than for other brands of } \\
\text { product Y }\end{array}$ \\
\hline 5 & $\begin{array}{l}\text { 1) I consider myself loyal to this brand. 2) I really love this brand 3) This } \\
\text { is a brand used by people like me 4) I am proud to have others know I use } \\
\text { this brand }\end{array}$ \\
\hline
\end{tabular}

Theoretically, Luxury consumptions contradicts with the value of communism, but it is ironically that China became the one of the most luxury consumption country. It is acknowledged that the features for Chinese luxury consumers are quite unique comparing with the countries' luxury customers. The first feature is their youth (Joann Ngai and Erin Cho, 2012). Most of the luxury consumers are under 40 years old and typically called post 1980 and post 1990 generation. Lu (2008) indicates that the general understanding of Chinese luxury consumers is that they are conspicuous and the social recognition of brands is the most important criterion for luxury shopping. It is mainly led by the fact Chinese consumers' buying decisions are most affected by Confucian values, which include collectiveness, harmonious interactions among in-group members, respect, and superiority (Wong and Ahuvia, 1998). Hung et al. (2011) have also argued that achievement vanity plays a significant role in Chinese consumer's purchasing decision. Chinese consumers therefore tend to see that the buying luxury is a way to show that they are successful and a way to elevate their social status (Ngai, 2012). Reuters (2018) has describe the features of new generation in luxury consumption, young, female and unafraid to spend.

\section{Social Media Platform}

In all over the word, people are more and more paying attention to social media platforms as an essential part of their routine life and move their vision to the virtual platforms (i.e. Facebook, Instagram, LinkedIn and Twitter). In views of traditional marketing, internet has been used as a method for advertising through the use of banner or sponsored (Oliveira,2014). Social media applications have been considered as one of the most efficient and efficient platforms that have been progressively engaged in most aspects of people's lives (i.e. social life, commercial life, business life, educational sector, political life) (Alalwan et al., 2016a; Algharabat et al., 2017; Abed et al., 2015; Hawkins and Vel, 2013; Hinz et al., 2011; Rathore et al., 2016; Usher et al., 2014; Zeng and Gerritsen, 2014; Zhu and Chen, 2015). For instance, from the perspective of the national governing bodies, social media could strategically enhance a two-way communication between firms and customers, and accordingly, attaching customers more with the organizations' brands (Alalwan et al.,2017). In China, Youtube, Facebook, Twitter and Instagram 
have been blocked by government (but the users can log in it by VPN). People in China mainly uses WeChat and Weibo.

Many organizations have been keeping much of their efforts and funds in social media marketing in engaging in existing social media to protect their corporation or brand reputation ( Lee and Youn, 2009), increase customer engagement or increase online sale (Gummerus, Liljander, Weman and Philstrom, 2012) or increase online sales (Tsimonis and Dimitriadis, 2014). Through WeChat, the customers could easily search and browse the luxury online store. It enhances the customers relationships and provides the luxury company with numerous exposure chances. Recent years, there are lots of literatures on social media for different platforms, such as YouTube, Facebook, Twitter and Instagram,

Social marketing in China has four features: high service and low cost, huge consumer base, content marketing and key opinion leaders (Wikipedia, 2017). WeChat allows the company to open an official account and service account if these companies are officially registered in China. WeChat users can subscribe it by browsing the company name or scanning QR code. Considering the huge population base, KOLs (refers to key opinion leaders) have huge influence in social media and its followers are loyal to his/her advice on products, especially in cosmetics sectors. These KOLs publish their photos, blogger, WeChat public account, Weibo and other social media platforms. The follows are quite loyal to these KOLs. In this paper, we would discuss the KOLs' importance in Discussion and Implication.

Hypothesis 1: The social media (WeChat) has a positive effect on service convenience.

Hypothesis 2: The social media (WeChat) function has a positive effect on Customer engagements.

Hypothesis 3: WeChat function has a positive effect on Customer equity.

\section{Service Convenience}

One of the key metrics of customer equity is service convenience. Merriam Webster defines convenience as "fitness or suitability for performing an action or fulfilling a requirement" (Merriam Webster,2017). It is also acknowledged to be substantially important to consumers, but few researches has defined the service convenience construct or examined how it is valued (Berry, 2002). One of the principal motivations for consumers to adopt online purchasing is shopping service convenience (Beauchamp and Ponder, 2010; Ling et al, 2012). Ling also describes that the five dimensions of online shopping convenience are access, search, evaluation, transaction, and possession/post-purchase convenience (Ling et al, 2012). Therefore, we further pose three hypotheses.

\section{Hypothesis 4: Service convenience has a positive impact on customer equity.}

\section{Hypothesis 5: Service convenience has a positive impact on customer engagement.}

\section{Hypothesis 6: Service convenience has a positive impact on purchase intention.}

\section{Customer Equity}

Customer equity is defined as the sum of the lifetime value of all customers of the firm, while customer lifetime is defined by the cash flow from the customers' future purchase (Kumar et al, 2015; Lemon, 2001). It creates long-term profit to most of the firms and is considered as the most precious asset (although the customer equity is not calculated and shown in balance sheet). Successful companies develop relationships with people and value customers relationships (Keyser, 2017). The frequent flyer mile, the loyalty card could be seen as an effective method to maintain and promote the customer equity. As WeChat moment, WeChat group and WeChat public account has been widely adopted in consuming industry, luxury firms need to examine whether it could spread its marketing campaign to Chinese luxury users. Therefore, four hypotheses have been developed as follows: 
Hypothesis 7: Customer equity has a positive impact on customer engagement.

Hypothesis 8: Customer equity has a positive impact on parasocial interact.

Hypothesis 9: Customer equity has a positive impact on purchase intention.

As the firms could create the news, advertisements and blogs in WeChat, it makes the customers easier to have a sub-sensory felling in front of the mobile phone's screen.

\section{Customer Engagement}

The firms play a key role in establishing the customer equity, but customers play a vital role in customers engagement sector. Increasing numbers of consumers are participating in online platforms to interact with other consumers and with brands and with merchandiser (Martínez-López ,2017; Kelley and Alden 2016, Tonteri et al. 2011). Customer engagement has been long recognized as one of the key drivers of a firm's financial success (Werner et al, 2017). The information and communication technologies, which have developed in conjunction with the rise of the Internet (e.g., social media, online brand communities), have served as influential engagement platforms facilitating interactions with and amongst consumers (Muñiz and O'Guinn, 2001; Muñiz and Schau, 2005; Gummesson and Mele, 2010). Buyers pass information on the company, its brand news, produces or service to other potential buyers that leads to rapidly growing network to spread the information (Dobele 2015, Dobele, Toleman et al. 2005, Lindgreen and Vanhamme 2005). It is believable that the social relationships could be enhanced by the customer engagement, as it provides the communication topic with friends.

TABLE 3

THE METHODS OF CUSTOMER ENGAGEMENT

\begin{tabular}{|c|l|l|}
\hline Category & \multicolumn{1}{|c|}{ Methods } & \multicolumn{1}{c|}{ Definition } \\
\hline $\mathbf{1}$ & Internet Forum & Internet forums, where people talk about different topics; \\
\hline $\mathbf{2}$ & Blogs & $\begin{array}{l}\text { blogs are services where users can post about many topics, the } \\
\text { most important blog services are these: Blogger, Tumblr and } \\
\text { WordPress. }\end{array}$ \\
\hline $\mathbf{3}$ & Social networking sites & $\begin{array}{l}\text { Another type of user-generated content are like Facebook, } \\
\text { Twitter, Instagram or VK, where users interact with other } \\
\text { people chatting, writing messages, or posting images or links. } \\
\text { Companies like YouTube allow users consume and produce } \\
\text { content. }\end{array}$ \\
\hline $\mathbf{4}$ & Smartphones Apps & $\begin{array}{l}\text { The latest but now the most common methods; internet } \\
\text { forums, blogs and social networking have introduced its own } \\
\text { apps into the market. }\end{array}$ \\
\hline
\end{tabular}

Hypothesis 10: Customer engagement has a positive effect on parasocial effect.

Hypothesis 11: Customer engagement has a positive effect on luxury purchase intention.

\section{Para Social Interaction (PSI)}

Para social interaction (PSI) indicates to the phenomena that the audience member expands their onesided relationships with the media (TV, Movie, Internet, etc). PSI could be explained as an illusionary experience that the media interact with persons (e.g., talk show host, celebrities, characters, sport star.) as like they really live, work, or interact with them (however, the truth is that the person and audience have no any interaction in social living). The concept of parasocial interaction was firstly introduced by Horton 
and Wohl (1956). McQuail et al. (1972) discovered this phenomenon described by Horton and Wohl in British early soap opera. The next major development in PSI research took place in North America, with Mark Levy's (1979) important study of older adults and local television news. In marketing sector, Labreque (2014) defies PSI, as "an illusionary experience, such that customers interact with personas (for example, mediated representation of presenters, celebrities, or characters) as if they are engaged in a reciprocal roles.

\section{Hypothesis 12: PSI has a positive effect on luxury purchase intention.}

\section{MODEL AND RESULT}

\section{Design}

The questionnaire is disseminated on WeChat by delivering the web-link and face-to-face filing in Shanghai downtown. The questionnaire has been designed by 7-piont Lickert-Scale type (1 indicates to totally disagree and 7 indicates to total agree). A small group of 15 students from business school and 5 marketing professors have participated in pretest and make their recommendation on correction and amelioration of questionnaires design. The total questionnaire sampling period has lasted for almost one month. SPSS 24 and AMOS 22 have been used to perform the exploratory factor analysis and confirmatory factor analysis separately. Based on literature review and hypothesis development, a conceptual model has been developed as fig. 3 shows.

\section{FIGURE 3}

\section{THEORETICAL MODEL OF SOCIAL MEDIA MARKETING OF LUXURY BY WECHAT}

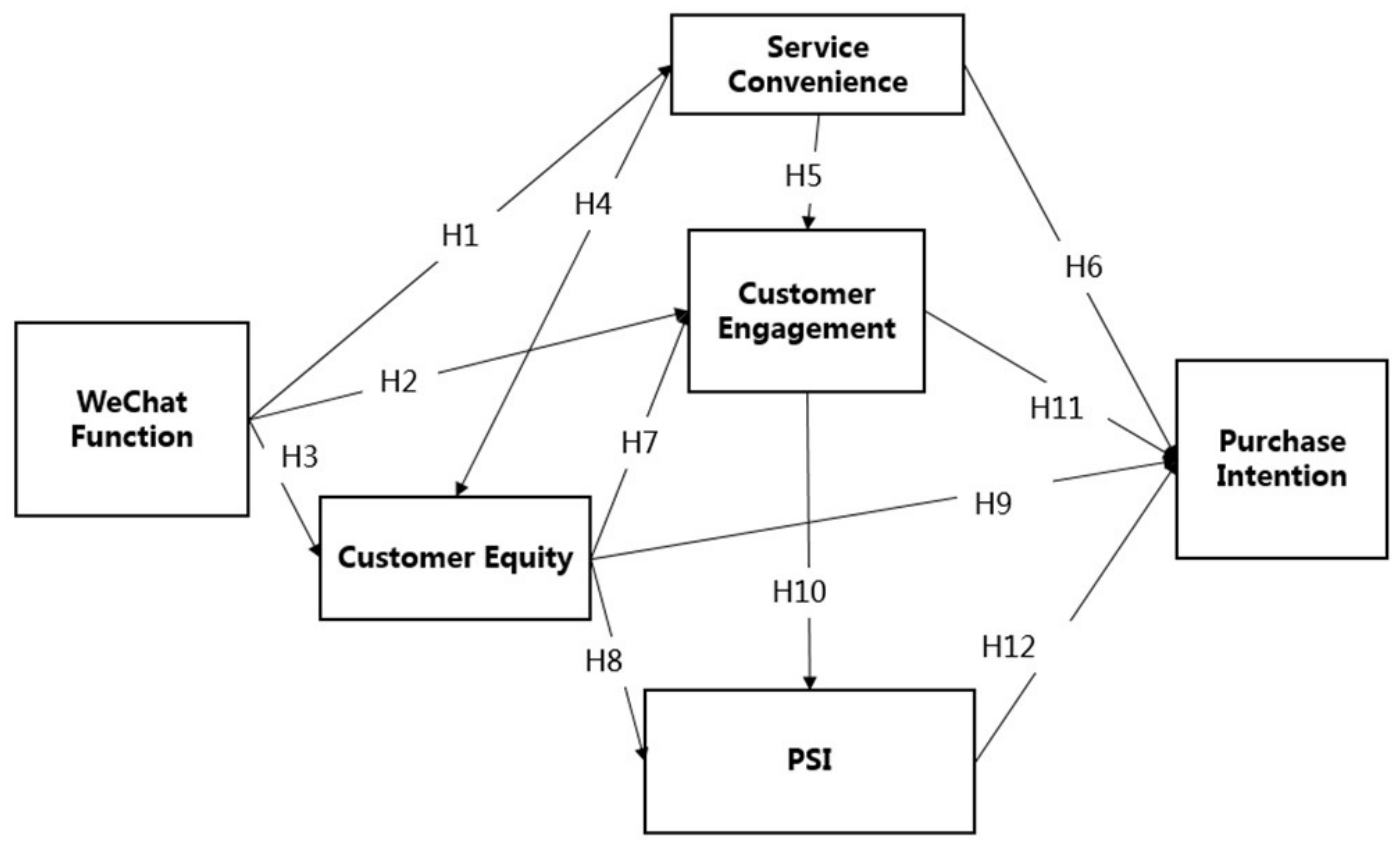

Table 4 illustrates the scale reference. As few researches intensify whether the WeChat is suitable for the dissemination of luxury goods, a new scale of WeChat Function has been developed for factor analysis. The scale of customer equity is also considered as a brand new one, as the WeChat has its own features in strengthening the customer equity. 
TABLE 4

CONCEPTUAL MODEL AND SCALE REFERENCE

\begin{tabular}{|l|l|c|}
\hline & & Scale Reference \\
\hline 1 & WeChat Function & New Scale \\
\hline 2 & Customer Equity & New Scale \\
\hline 3 & Service Convenience & Bellenger and Korgaonkar (1980), Jiang et al (2012) \\
\hline 4 & Para Social Interact & Lee (2016), Labrecque (2014). \\
\hline 5 & Customer engagement & Popp (2016) \\
\hline 6 & Purchase Intention & \\
\hline
\end{tabular}

Exploratory factor ` at test whether the model fits the hypothesized measurement model.

\section{Descriptive Analysis}

$72.5 \%$ of the respondents are female while the rest of $27.5 \%$ are male. Most of the correspondents are below 25 years old and undertake a study program in university. Their annual householder incomes are mostly under 300,000 RMB.

TABLE 5

\section{DEMOGRAPHIC TRAITS}

\begin{tabular}{|c|c|c|c|c|c|}
\hline Variable & Demographic traits & $\%$ & Variable & Demographic traits & $\%$ \\
\hline \multirow[t]{2}{*}{ Gender } & Male & 27.5 & \multirow[t]{2}{*}{ Education } & $\begin{array}{l}\text { Bachelor's degree or non-higher } \\
\text { education degree }\end{array}$ & 91.6 \\
\hline & Female & 72.5 & & Master's degree and PhD Degree & 8.4 \\
\hline \multirow{4}{*}{ Age } & $\begin{array}{l}\text { Below } 25 \text { years } \\
\text { old }\end{array}$ & 71.6 & \multirow{4}{*}{$\begin{array}{l}\text { Annul } \\
\text { income }\end{array}$} & Lower than $150,000 \mathrm{RMB}$ & 32.4 \\
\hline & $\begin{array}{l}\text { Between 25-35 } \\
\text { years old }\end{array}$ & 16.0 & & Between 150,000-300,000 RMB & 47.0 \\
\hline & $\begin{array}{l}\text { Between } 35-50 \\
\text { years old }\end{array}$ & 11.7 & & Between 300,000-500,000 RMB & 14.0 \\
\hline & $\begin{array}{l}\text { Above } 50 \text { years } \\
\text { old }\end{array}$ & 0.6 & & Above 500,000 RMB & 6.6 \\
\hline
\end{tabular}

\section{Results}

To assess measurements of the constructs, exploratory factor analysis was conducted using the maximum likehood estimation with oblimin rotation. As table 6 Shows below, the Cronbach alpha for all the questionnaire reaches 0.94 (above the excellent value of 0.9 , George 2003), showing that the overall credibility is very convincible. Any of sub-categories' Cronbach alpha is above 0.7 and KMO is above 0.6 , approving that the result is satisfactory. The CFA result shows that the model reliable also, because all the factors have past the minimum threshold $(\mathrm{CR}>0.7 \mathrm{AVE}>0.5)$. For discriminant validity, which denotes the extent to which the measures for each construct are distinct from each other, we performed the assessment by verifying whether the correlations between a referent construct with others are substantially different from the square roots of the AVE scores of that construct (Anderson, 1987). 
TABLE 6

RESULT OF EXPLORATORY FACTOR ANALYSIS AND CONFIRMATORY

FACTOR ANALYSIS

\begin{tabular}{|c|c|c|c|c|c|c|c|c|c|c|c|c|}
\hline & \multicolumn{3}{|c|}{ EFA } & \multicolumn{2}{|c|}{ CFA } & \multicolumn{6}{|c|}{ Correlation } \\
\hline & & Alpha & Var & KMO & CR & AVE & WF & \multirow[t]{3}{*}{$\mathrm{CE}$} & \multirow[t]{3}{*}{ SC } & \multirow[t]{3}{*}{ PSI } & \multirow[t]{3}{*}{ CE } & \multirow[t]{3}{*}{ PI } \\
\hline \multirow{2}{*}{$\begin{array}{l}\text { WeChat } \\
\text { Function } \\
\text { (WF) }\end{array}$} & WF1 & \multirow[b]{2}{*}{0.72} & \multirow[b]{2}{*}{0.65} & \multirow[b]{2}{*}{0.65} & \multirow[b]{2}{*}{0.72} & \multirow[b]{2}{*}{0.56} & \multirow[b]{2}{*}{0.75} & & & & & \\
\hline & WF2 & & & & & & & & & & & \\
\hline \multirow{3}{*}{$\begin{array}{c}\text { Customer } \\
\text { equity } \\
\text { (CE) }\end{array}$} & CE1 & \multirow{3}{*}{0.89} & \multirow{3}{*}{0.703} & \multirow{3}{*}{0.703} & \multirow{3}{*}{0.70} & \multirow{3}{*}{0.89} & \multirow{3}{*}{0.73} & \multirow{3}{*}{0.94} & & & & \\
\hline & CE2 & & & & & & & & & & & \\
\hline & CE3 & & & & & & & & & & & \\
\hline \multirow{3}{*}{$\begin{array}{c}\text { Service } \\
\text { Convenience } \\
\text { (SC) } \\
\end{array}$} & $\mathrm{SC} 1$ & \multirow{3}{*}{0.84} & \multirow{3}{*}{0.707} & \multirow{3}{*}{0.707} & \multirow{3}{*}{0.64} & \multirow{3}{*}{0.84} & \multirow{3}{*}{0.58} & \multirow{3}{*}{0.62} & \multirow{3}{*}{0.92} & & & \\
\hline & $\mathrm{SC} 2$ & & & & & & & & & & & \\
\hline & $\mathrm{SC} 3$ & & & & & & & & & & & \\
\hline & PSI1 & & & & & & & & & & & \\
\hline Interact & PSI2 & 087 & 081 & 081 & 081 & 0.87 & 044 & 044 & 0.45 & 0.93 & & \\
\hline (PSI) & $\begin{array}{c}\text { PSI3 } \\
\text { PS4 }\end{array}$ & 0.07 & 0.01 & & & & & & & & & \\
\hline & CG1 & & & & & & & & & & & \\
\hline $\begin{array}{l}\text { Customer } \\
\text { Enoagement }\end{array}$ & CG2 & 090 & 0852 & 0852 & 0.97 & 077 & 044 & 042 & 0.4 & 070 & 085 & \\
\hline (CE & CG3 & 0.91 & 0.852 & 0.852 & 0.92 & 0.12 & 0.41 & 0.42 & 0.44 & 0.10 & 0.85 & \\
\hline & CG4 & & & & & & & & & & & \\
\hline & PI1 & & & & & & & & & & & \\
\hline $\begin{array}{l}\text { Purchase } \\
\text { Intention }\end{array}$ & PI2 & 0.90 & 0.807 & 0.807 & 0.99 & 0.71 & 0.51 & 0.57 & 0.55 & 0.73 & 0.78 & 0.84 \\
\hline (PI) & $\begin{array}{l}\text { PI3 } \\
\text { PI4 }\end{array}$ & & & & & & & & & & & \\
\hline
\end{tabular}

Notes: $\mathrm{CR}=$ composite reliability; $\mathrm{AVE}=$ average variance extracted. The diagonal (in italics) shows the square root of the AVE for each construct; the off-diagonal numbers represent the correlations among constructs.

The model's goodness of fit is desirable, with a CMIN/DF ratio of 3.247 (March \& Hocevar), RMESA ratio of 0.08 (Browne and Cudeck, 1993). 


\section{CONCLUSION}

FIGURE 4

THE PATH ANALYSIS RESULTS OF STRUCTURE EQUATION MODELING

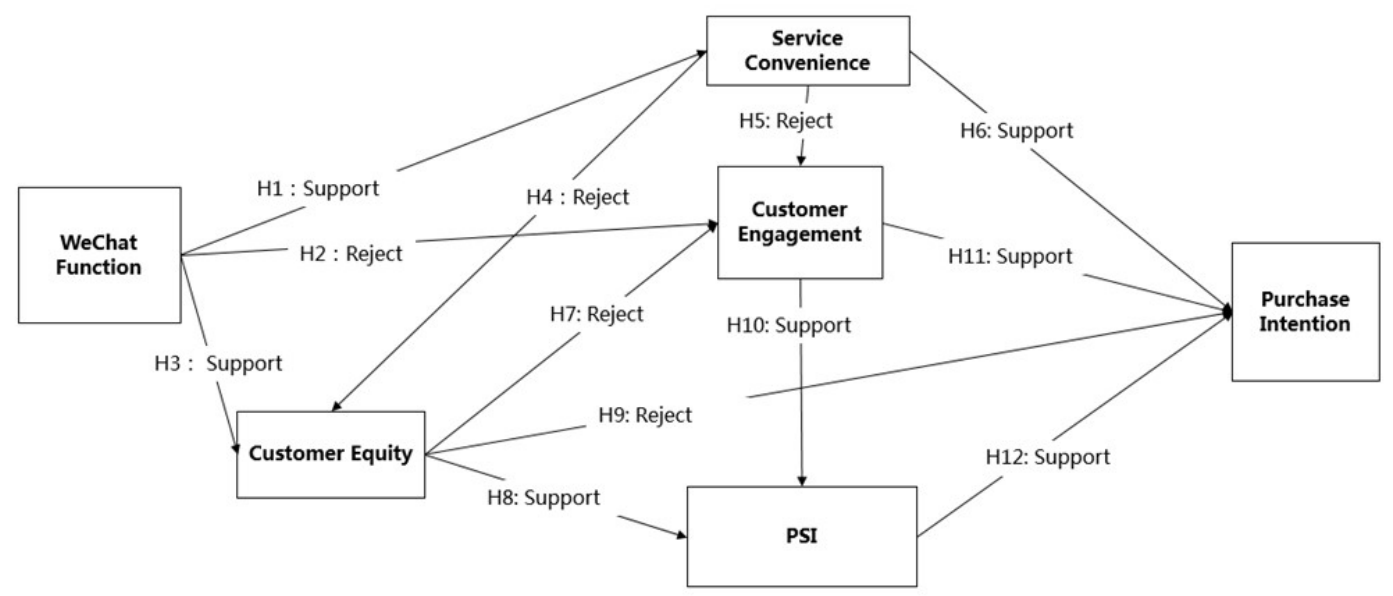

( $\mathrm{p}$ value $<0.001, \mathrm{CMINDF}=3.247, \mathrm{RMESA}=0.8, \mathrm{GFI}=0.874, \mathrm{NFI}=0.91, \mathrm{AGFI}=0.828, \mathrm{CFI}=0.935, \mathrm{TLI}=0.92$ )

As Fig.4 shows, seven of the twelve hypotheses have been supported and rest of fives have been considered as insignificant and rejected (shown in table 7), at a significant level of 0.001 . It has been concluded that WeChat makes benefit for service convenience in luxury industry $(C R=9.60, p<0.001)$, however this convenience doesn't indicate to increasing customer equity $(\mathrm{CR}=0.48, \mathrm{p}=0.663)$. The reason might be indicating that luxury is a good with strong sensory feeling. The service provided by internet doesn't provide enough information or experience for luxury buyers. It is a little bit surprising that WeChat provides the customers with ambiguous benefit in customer engagement $(\mathrm{CR}=1.59$ and $\mathrm{P}$ Value $=0.112$ ), but the customer equity has been enhanced by WeChat $(\mathrm{CR}=5.97$ and $\mathrm{P}$ Value $<0.001)$. Although WeChat has a huge user base and penetration in Chinese ordinary living, its convenience hasn't significant contribution on increasing customer equity $(\mathrm{CR}=0.48$ and $\mathrm{P}$ Value $=0.663)$ and customer engagement $(\mathrm{CR}=1.34$ and $\mathrm{P}$ Value $=0.18)$. However, it is widely accepted that service convenience has a positive impact on purchase intention $(\mathrm{CR}=3.26$ and $\mathrm{P}$ Value $=0.001)$. Regarding to the customer equity, it can lead to increasing PSI $(\mathrm{CR}=3.77$ and $\mathrm{P}$ Value $<0.001)$ effect but failed to deliver its contribution to customer engagement $(\mathrm{CR}=-0.48$ and $\mathrm{P}$ Value $=0.633)$. Surprisingly, customer equity doesn't lead to a clear effect on purchase decision $(\mathrm{CR}=0.99$ and $\mathrm{P}$ Value $=0.32)$. Regarding to the customer engagement, it has a clear effect on PSI $(\mathrm{CR}=12.56$ and $\mathrm{P}$ Value $=0.001)$. Both customer and PSI has a significant influence on luxury purchase intention. 
TABLE 7

RESULT OF CONFIRMATORY FACTOR ANALYSIS

\begin{tabular}{|c|c|c|c|c|c|c|}
\hline & Hypothesis & Estimator & S.E. & $\begin{array}{l}\text { Critical } \\
\text { Ratio }\end{array}$ & P Value & Conclusion \\
\hline H1 & $\begin{array}{l}\text { WeChat function has a } \\
\text { positive effect on service } \\
\text { convenience. }\end{array}$ & 0.77 & 0.08 & 9.60 & $<0.001$ & $\begin{array}{l}\text { Significant, and Support } \\
\text { the hypothesis }\end{array}$ \\
\hline $\mathrm{H} 2$ & $\begin{array}{l}\text { WeChat function has a } \\
\text { positive effect on } \\
\text { Customer engagements }\end{array}$ & 0.47 & 0.30 & 1.59 & 0.112 & $\begin{array}{l}\text { Not significant, and reject } \\
\text { the hypothesis }\end{array}$ \\
\hline H3 & $\begin{array}{l}\text { WeChat function has a } \\
\text { positive effect on } \\
\text { Customer equity }\end{array}$ & 1.14 & 0.19 & 5.97 & $<0.001$ & $\begin{array}{l}\text { Significant, and Support } \\
\text { the hypothesis }\end{array}$ \\
\hline H4 & $\begin{array}{l}\text { Service convenience has a } \\
\text { positive impact on } \\
\text { customer equity }\end{array}$ & -0.19 & 0.18 & 0.48 & 0.633 & $\begin{array}{l}\text { Not significant, and reject } \\
\text { the hypothesis }\end{array}$ \\
\hline H5 & $\begin{array}{l}\text { Service convenience has a } \\
\text { positive impact on } \\
\text { customer engagement. }\end{array}$ & 0.23 & 0.17 & 1.34 & 0.18 & $\begin{array}{l}\text { Not significant, and reject } \\
\text { the hypothesis }\end{array}$ \\
\hline H6 & $\begin{array}{l}\text { Service convenience has a } \\
\text { positive impact on } \\
\text { purchase intention. }\end{array}$ & 0.215 & 0.07 & 3.26 & 0.001 & $\begin{array}{l}\text { Significant, and Support } \\
\text { the hypothesis }\end{array}$ \\
\hline H7 & $\begin{array}{l}\text { Customer equity has a } \\
\text { positive impact on } \\
\text { customer engagement. }\end{array}$ & -0.08 & 0.16 & -0.48 & 0.633 & $\begin{array}{l}\text { Not significant, and reject } \\
\text { the hypothesis }\end{array}$ \\
\hline H8 & $\begin{array}{l}\text { Customer equity has a } \\
\text { positive impact on PSI. }\end{array}$ & 0.17 & 0.05 & 3.77 & $<0.001$ & $\begin{array}{l}\text { Significant, and Support } \\
\text { the hypothesis }\end{array}$ \\
\hline H9 & $\begin{array}{l}\text { Customer equity has a } \\
\text { positive impact on } \\
\text { purchase intention. }\end{array}$ & 0.05 & 0.05 & 0.99 & 0.32 & $\begin{array}{l}\text { Not significant, and reject } \\
\text { the hypothesis }\end{array}$ \\
\hline H10 & $\begin{array}{l}\text { Customer engagement has } \\
\text { a positive effect on PSI }\end{array}$ & 0.73 & 0.06 & 12.56 & $<0.001$ & $\begin{array}{l}\text { Significant, and Support } \\
\text { the hypothesis }\end{array}$ \\
\hline H11 & $\begin{array}{l}\text { Customer engagement has } \\
\text { a positive effect on luxury } \\
\text { purchase intention. }\end{array}$ & 0.75 & 0.08 & 9.79 & $<0.001$ & $\begin{array}{l}\text { Significant, and Support } \\
\text { the hypothesis }\end{array}$ \\
\hline H12 & $\begin{array}{l}\text { PSI has a positive effect on } \\
\text { luxury purchase intention }\end{array}$ & 0.23 & 0.07 & 3.51 & $<0.001$ & $\begin{array}{l}\text { Significant, and Support } \\
\text { the hypothesis }\end{array}$ \\
\hline
\end{tabular}

\section{DISCUSSION AND IMPLICATION}

This research provides a timely and resourceful reference for both academic and managerial field. It is interested to be noted that WeChat is still developing in a fast track and planning to calibrate the international shares. Thanks to its contribution, on 27th November 2017, Tencent (WeChat's inventor and operator) has surpassed Facebook in value after it became the first company in China to be worthy more than $\$ 500$ billion (Telegraph, 2017). China is no doubt one of the biggest luxury goods consumption country in terms of its population and volume. It is no doubt that practitioners and scholars, especially in commercial and business sector, should put emphasis on the extension of research in this area. 


\section{Theoretical Implication}

This research paper has contributed the marketing literature in the following ways: first, this paper has filled the gap in the social marketing by adopting the service convenience; second, it is the first research paper to examine how WeChat provides the benefits to Chinese luxury buyers.

\section{Managerial Implication}

The above results indicate to the fact that Customer engagement and para social effect has positive effect on the luxury purchase intention. However, although WeChat provides a very convenient and powerful payment tool and online service, it has an opposite effect on luxury purchase intention. The main reason might be that the luxury is viewed as exclusive and mysterious. The wealthy luxury buyer tends to enjoy the high standard service in a real shop, instead of the virtual online shops. In China, the people feel no hesitation to buy a normal goods in online shop. However, luxury goods are sold at a higher price. The luxury goods in internet are linked with the purchasing agent (the person who buys the goods in a foreign country and brings back to China to sell online, to gain a price different and tax refunds.). In fact, the luxury companies are very cautious in their online strategies. Traditionally, luxury needs to maintain its exclusivity and distance to the non-aristocratic and ordinary people; however, it increasingly relies on the middle class to sustain its sustainable growth. Online marketing has left the impression of promotion and discount for a goods, that jeopardize the long term sustainable development for luxury goods. Comparing with other brand community, luxury brand community has low influence on the luxury purchase intention. It might be the result that Chinese young customers are not willing to share their luxury purchase intention to their close friends.

Traditional social marketing has been proved as an inefficient way to do the marketing. However, it doesn't mean that internet marketing or social marketing is a forbidden area for luxury company. Luxury company should promote the indirect way to do the marketing, which encourages Customer engagement and PSI effect. There are lots of active bloggers and micro bloggers in Weibo and WeChat, sharing their fascinating experience in owning luxury goods and posing their luxury purchase advice in internet.

\section{Limitation}

The sampling has been mainly collected by university students in Shanghai and Yangtze delta area. The residential income in this area is higher than the Chinese national level and its luxury consuming behavior is more prevailing than other part of country. However, the economic development inequality exits in China. It needs both managerial and academical experts to put more emphasis on it. Especially there is huge regional difference between North China and Southern China, or Western China and Eastern China, or 1st tier cities and 2nd tier cities. Further study should notice these differences and make analysis for each category of groups.

\section{FUTURE RESEARCH}

Alongside with the rapid development of Chinese economy, research on Chinese luxury has attracted much more attention than before. Other social platforms in China outside of WeChat needs to be investigated, such as Sina Weibo (Microblog), Youku (Like Youtube) and other social media platform.

\section{ACKNOWLEDGEMENT}

The author gratefully acknowledges the editors of journal of management decision, who has contributed for the advice and improvement of this research paper. I would also to extend my appreciation to my current working Shanghai Jian Qiao University for academic support and other necessary assistance in my research. 


\section{REFERENCES}

Anderson, J.C. (1987). An approach for confirmatory measurement and structural equation modelling of organizational properties. Management Science, 33(4), 525-541.

Beauchamp, M.B., \& Ponder, N. (2010). Perceptions of retail convenience for in-store and online shoppers. The Marketing Management Journal, 20(1), 49-65.

Bellenger, D.N., \& Korgaonkar, P.K. (1980). Profiling the recreational shopper. Journal of Retailing, 56, 77-92.

Branigan, T. (2011, April 26). China's taste for high-end fashion and luxury brands reaches new heights. The Guardian. Retrieved from www.guardian.co.uk/world/2011/apr/26/china-super-richdemandluxury-brands

Dhaoui, C. (2014). Anempirical study of luxury brandmarketing effectiveness and its im- pact on consumer engagement on Facebook. Journal of Global Fashion Marketing, 5(3), 209-222.

Dobele, A.R., Toleman, D., \& Beverland, M. (2005). Controlled infection! Spreading the brand message through viral marketing. Business Horizons, 48(2), 143-149.

Gummerus, J., Liljander, V., Weman, E., \& Pihlström, M. (2012). Customer engagement in a Facebook brand community. Management Research Review, 35(9), 857-877.

Hodeghatta, U.R., \& Sahney, S. (2016). Understanding Twitter as an e-WOM. Journal of Systems and Information Technology, 18(1), 89-115.

Horton, D., \& Wohl, R.R. (1956). Mass communication and para-social interaction. Psychiatry, 19, 215229.

Hung, K., Chen, A.H., Peng, N., Hackley, C., \& Rungpaka, A.T. (2011). Antecedents of luxury brand purchase intention. Journal of Product \& Brand Management, 20(6), 457-67.

Jöreskog, K.G. (1969). A general approach to confirmatory maximum likelihood factor analysis. Psychometrika, 34(2), 183-202.

Kelley, J. B., \& Alden, D.L. (2016). Online brand community: through the eyes of SelfDetermination Theory. Internet Research, 26(4), 790-808.

Labrecque, L.I. (2014). Fostering consumer-brand relationships in social media environments: The role of para-social interaction. Journal of Interactive Marketing, 28, 134-148.

Lee, J.E., \& Watkins, B. (2016). YouTube vloggers' influence on consumer luxury brand perceptions and intentions. Journal of Business Research. http://dx.doi.org/10.1016/j.jbusres.2016.04.171

Lee, M., \&Young, S. (2009). Electronic word of mouth (eWOM) How eWOM platforms influence consumer product judgement. International Journal of Advertising, 28(3), 473-499.

Lindgreen, A., \& Vanhamme, J. (2005). Viral marketing: The use of surprise. Advances in electronic marketing. In I. C. Clarke \& T. B. Flaherty (pp. 122-138). Hershey, PA, Idea Group.

Lu, X. (2008). Elite China: Luxury Consumer Behavior in China. Wiley, Singapore.

Lusch, R.F., \& Vargo, S.L. (2006). Service-Dominant Logic as a Foundation for Building a General Theory. In R. F. Lusch and S. L. Vargo (Eds.), The Service-Dominant Logic of Marketing (pp. 406-420). Armonk, NY: M.E. Sharpe.

Marsh, H.W., \& Hocevar, D. (1985). Application of confirmatory factor analysis to the study of selfconcept: First- and higher order factor models and their invariance across groups. Psychological Bulletin, 97(3), 562-582.

McQuail, D., Blumler, J.G., \& Brown, J.R. (1972). The television audience: A revised perspective. In D. McQuail (Ed.), Sociology of mass communications: Selected readings (pp. 135-165).

Harmondsworth: Penguin.

Mike, S. (2014). Fashion brands like Chanel and Dior are starting to figure out YouTube. The Wall Street Journal. Retrieved from http://blogs.wsj.com/cmo/2014/09/10/ fashion-brands-like-chanel-anddior-are-starting-to-figure-out-youtube

Muñiz, A., \& O'Guinn, T. (2001). Brand community. Journal of Consumer Research, 27(4), 412-432.

Muñiz, A., \& Schau, H.J. (2005). Religiosity in the abandoned Apple Newton community. Journal of Consumer Research, 31(4), 737-747.

64 Journal of Marketing Development and Competitiveness Vol. 14(4) 2020 
Ngai, J., \& Cho, E. (2012). The young luxury consumers in China. Young Consumers, 13(3), 255-266.

Norris, M., \& Lecavalier, L. (2009, July 17). Evaluating the Use of Exploratory Factor Analysis in Developmental Disability Psychological Research. Journal of Autism and Developmental Disorders, 40(1), 8-20. doi:10.1007/s10803-009-0816-2

Park, J., Song, H., \& Ko, E. (2011). The effect of the lifestyles of social networking service users on luxury brand loyalty. Journal of Global Scholars of Marketing Science, 21(4), 182-192.

Schau, H., Muñiz, A., Jr., \& Arnould, E. (2009). How brand community practices create value. Journal of Marketing, 73(5), 30-51.

Tonteri, L., Kosonen, M., Ellonen, H.K., \& Tarkiainen, A. (2011). Antecedents of an experienced sense of virtual community. Computers in Human Behaviour, 27(6), 2215-2223.

Tsimonis, G., \& Dimitriadis, S. (2014). Brand strategies in social media. Marketing Intelligence and Planning, 32(3), 328-344

Wong, N.Y., \& Ahuvia, A.C. (1998). Personal taste and family face: luxury consumption in Confucian and western societies. Psychology \& Marketing, 15(5), 423-41. 


\section{APPENDIX}

\section{QUESTIONNAIRE AND SCALE}

\begin{tabular}{|c|c|c|}
\hline \multicolumn{2}{|l|}{ Gender } & $\begin{array}{l}\text { Male } \\
\text { Female }\end{array}$ \\
\hline \multicolumn{2}{|l|}{ Age } & $\begin{array}{l}\text { Below than } 25 \text { years ago. } \\
\text { Between } 25 \text { and } 35 \text { years ago } \\
\text { Between } 35 \text { and } 50 \text { years ago } \\
\text { More than } 50 \text { years ago }\end{array}$ \\
\hline \multicolumn{2}{|l|}{ Annual Income } & $\begin{array}{l}\text { Less than three hundred thousand } \\
\text { Between three hundred thousand and eight hundred thousand } \\
\text { More than eight hundred thousand }\end{array}$ \\
\hline \multicolumn{2}{|c|}{ Educational background } & $\begin{array}{l}\text { Bachelor or below degree } \\
\text { Master or above degree }\end{array}$ \\
\hline \multirow{2}{*}{ WeChat } & WC1 & WeChat could boost luxury dispersion for friends. \\
\hline & WC2 & WeChat will not damage the luxury brand image \\
\hline \multirow{3}{*}{ Customer Equity } & CE1 & $\begin{array}{l}\text { Post the luxury news to WeChat friend could advertise luxury in } \\
\text { a better way. }\end{array}$ \\
\hline & CE2 & $\begin{array}{l}\text { Post my experience or usage in WeChat moment could advertise } \\
\text { luxury in a better way }\end{array}$ \\
\hline & CE3 & $\begin{array}{l}\text { Establish WeChat friend chat group and let the WeChat friends } \\
\text { joining in could advertise luxury in a better way }\end{array}$ \\
\hline \multirow{3}{*}{$\begin{array}{c}\text { Service } \\
\text { Convenience }\end{array}$} & Service Convenience 1 & $\begin{array}{l}\text { By communicating with store sales through WeChat, I will } \\
\text { directly use WeChat to pay the purchase }\end{array}$ \\
\hline & Service Convenience 2 & $\begin{array}{l}\text { I think WeChat and e-mall make luxury pricing and quality more } \\
\text { transparent }\end{array}$ \\
\hline & Service Convenience 3 & $\begin{array}{l}\text { If I can communicate with customer service through WeChat, I } \\
\text { am more comfortable with the purchase and after-sales service }\end{array}$ \\
\hline \multirow{4}{*}{$\begin{array}{l}\text { Para Social } \\
\text { Interact }\end{array}$} & PSI 1 & I always imitate my friends' choice on luxury consumption. \\
\hline & PSI2 & $\begin{array}{l}\text { I acknowledge how the celebrities wear by WeChat's publication } \\
\text { account. }\end{array}$ \\
\hline & PSI3 & $\begin{array}{l}\text { I feel in the same community of friends/celebrity by imitation of } \\
\text { their wearing. }\end{array}$ \\
\hline & PS4 & I do shopping where the celebrities/friends have been to. \\
\hline \multirow{4}{*}{$\begin{array}{l}\text { Customer } \\
\text { engagement }\end{array}$} & UGC1 & $\begin{array}{l}\text { I often participate in the discussion of luxury goods (e.g. } \\
\text { WeChat Subscription message, etc.) }\end{array}$ \\
\hline & UGC2 & I'll post photos of me using luxury in my WeChat moment \\
\hline & UGC3 & I will actively write some luxury use and maintenance tips \\
\hline & UGC4 & $\begin{array}{l}\text { I encourage my friends to spread their experiences of } \\
\text { buying/using luxury }\end{array}$ \\
\hline \multirow{4}{*}{$\begin{array}{l}\text { Purchase } \\
\text { Intention }\end{array}$} & BUY1 & I often acquire luxury news through WeChat \\
\hline & BUY2 & I think WeChat has increased my chances of buying luxury \\
\hline & BUY3 & I think it's very convenient to buy luxury through WeChat \\
\hline & BUY4 & $\begin{array}{l}\text { I will use the WeChat moment to spread the process and news of } \\
\text { purchasing luxury }\end{array}$ \\
\hline
\end{tabular}

